\title{
Analysis of Agroforestry Farming Income in Boalemo Regency
}

\section{Ulfiasih ${ }^{1}$, Dewa Oka Suparwata', Taufik Jarot Andrayanto', Meity M. Mokoginta ${ }^{1}$ \\ ${ }^{1}$ Agribusiness Study Program, Faculty of Agricultural Sciences, Muhammadiyah University of Gorontalo, Indonesia}

\begin{abstract}
Agroforestry is a farming system that is carried out by integrating agricultural crops with forestry crops. This research was conducted in Boalemo District in April 2018. The purpose of this study was to calculate the total income of agroforestry farming. Data were analyzed using a method of analyzing farm income for each crop commodity, while total income was derived from the accumulation of income for each commodity. The results showed that agroforestry in Boalemo was classified as simple agroforestry and early agroforestry with agrisilvikultur type. Total agroforestry income (PTA) is Rp.205.055.153/ha/year, with a total revenue Rp. 249.280.098/ha/year and the total cost of Rp. 44.224.945/ha/year.
\end{abstract}

Keywords: Income analysis, Agroforestry, Boalemo

Introduction

Agroforestry is a farming system that combines agricultural crops with forestry crops. This component is usually managed at the same time taking into account the economic value, environmental balance (ecology) and social value. Agroforestry is also a farming system that is able to obtain quite a variety of agricultural products, and provides benefits from various sides. Fanish \& Priya (2013), stated that agroforestry provides benefits such as increasing productivity, soil fertility, soil conservation, increasing water use efficiency, microclimate improvement, biodiversity conservation, bio-drainage and carbon sequestration.

In Indonesia, many farmers have implemented farming through agroforestry systems with different combination patterns. However, the terms agroforestry are less well known among the people. In general, farmers only know how to manage forests with the aim of meeting their daily needs, so that some farmers who cultivate through this system do not take into account how much profit (profit) they get from each commodity, both short-term and long-term benefits.

Boalemo Regency is one of the regencies that has a fairly wide dry land, which is 39,214 ha (BPS Kabupaten Boalemo, 2015). The habit of most farmers who carry out monoculture farming causes several environmental problems (land degradation), so the government of Boalemo Regency replaces corn plants with annual crops such as cocoa, cloves, pepper, and nutmeg (Azhar, 2015 in Khasanah et al., 2016).

Some farmers in Boalemo Regency have done agroforestry farming and others have not implemented it because most farmers also need evidence in the form of profit or income data obtained by farmers as information on the success of their agroforestry farming. So that some other farmers can accept and adopt new systems or knowledge. Previous research on agroforestry has been carried out by Mulyana (2017) with the aim of explaining forest management systems and agroforestry performance in the Protected Forest Management 
Unit area. Based on the description above, the researchers are interested in conducting research with the aim of calculating the economic valuation of agroforestry farming.

\section{Methods}

This research was conducted in Boalemo Regency, Gorontalo Province. The location of this research was chosen deliberately with several considerations, namely; 1 ) the research location is an area that is mostly dry land and has the potential to be applied to agroforestry; 2 ) the research location is one of the locations where the farmers have implemented agroforestry farming. This research will be conducted in April 2018.

The population in this study were dry land farmers in Boalemo Regency. The selected farmers are farmers who have implemented agroforestry systems in their farming techniques. The population in this study amounted to 75 agroforestry farmers.

The sampling technique used is the saturation sampling method. According to Silaen \& Widiyono (2013), the saturated sample technique is used when the total population is small, generally not more than 100 . The total population in this study was 75 farmers. To determine the diversity of the types of combination patterns cultivated, the entire population of agroforestry farmers in Boalemo Regency was used as a sample.

According to Sundari (2011), income is the difference between total revenue and total cost, while revenue is obtained by multiplying the amount of production per hectare by the selling price.

$$
\mathbf{T I}=\mathbf{T R}-\mathbf{T C}
$$

information:

$$
\begin{aligned}
\mathrm{TI} & =\text { total income } \\
\mathrm{TR} & =\text { total revenue } \\
\mathrm{TC} & =\text { total cost }
\end{aligned}
$$

Income from food crops (corn)

$$
\mathbf{I}_{\mathrm{tp}}=\mathbf{R}_{\mathrm{tp}}-\mathbf{C}_{\mathbf{t p}}
$$

information:

$$
\begin{aligned}
& I_{t p}=\text { income from food crops }(\mathrm{Rp} / \text { ha/year) } \\
& R_{t p}=\text { receipt of food crops }(\mathrm{Rp} / \mathrm{ha} / \text { year }) \\
& \mathrm{C}_{\mathrm{tp}}=\text { management costs of food crops (Rp/ha/year) }
\end{aligned}
$$

Income from horticultural crops (spices and fruits)

$$
\mathbf{I}_{\text {th }}=\mathbf{R}_{\mathrm{th}}-\mathbf{C}_{\mathrm{th}}
$$

information :

$$
\begin{aligned}
& I_{\text {th }}=\text { income from horticultural crops (Rp/ha/year) } \\
& \mathrm{R}_{\text {th }}=\text { receipt of horticultural plants (Rp/ha/year) } \\
& \mathrm{C}_{\text {th }}=\text { horticultural plant management costs (Rp/ha/year) }
\end{aligned}
$$

Income from plantation crops (cocoa, coconut, cloves, nutmeg, palm)

$$
\mathbf{I}_{\mathbf{k b}}=\mathbf{R}_{\mathbf{k b}}-\mathbf{C}_{\mathbf{k b}}
$$

$\mathrm{I}_{\mathrm{kb}}=$ income from plantation crops (Rp/ha/year) 
$\mathrm{R}_{\mathrm{kb}}=$ receipt of plantation crops $(\mathrm{Rp} / \mathrm{ha} /$ year $)$

$\mathrm{C}_{\mathrm{kb}}=$ cost of plantation crop management (Rp/ha/year)

Income from forestry plants (teak, mahogany, gmelina, jabon, gamal)

$$
\mathbf{I}_{\mathbf{k h}}=\mathbf{R}_{\mathbf{k h}}-\mathbf{C}_{\mathbf{k h}}
$$

information:

$$
\begin{aligned}
& I_{k h}=\text { income from forestry plants (Rp/ha/year) } \\
& R_{k h}=\text { receipt from forestry plants (Rp/ha/year) } \\
& C_{c}=\text { management costs of forestry plants (Rp/ha/year) } \\
& k_{k h}
\end{aligned}
$$

Total agroforestry revenue

$$
\mathbf{I T A}=\mathbf{I}_{\mathrm{tp}}+\mathbf{I}_{\mathbf{t h}}+\mathbf{I}_{\mathbf{k b}}+\mathbf{I}_{\mathbf{k h}}
$$

information :

$$
\begin{aligned}
& I_{\text {ta }}=\text { total agroforestry income (Rp/ha/year) } \\
& I_{\text {tp }}=\text { income from food crops (Rp/ha/year) } \\
& I_{\text {th }}=\text { income from horticultural crops (Rp/ha/year) } \\
& I_{\mathrm{kb}}=\text { income from plantation crops (Rp/ha/year) } \\
& I_{\mathrm{kh}}=\text { income from forestry plants (Rp/ha/year) }
\end{aligned}
$$

\begin{tabular}{|c|c|c|c|c|}
\hline Commodities & Plant & Used & Total (Ha) & Percentage (\%) \\
\hline Food & Corn & 50,35 & 50,35 & 35,84 \\
\hline \multirow{4}{*}{ Plantation } & Cocoa & 5,13 & \multirow{4}{*}{20,12} & \multirow{4}{*}{14,32} \\
\hline & Coconut & 9,50 & & \\
\hline & Clove & 4,19 & & \\
\hline & Shovel & 1,31 & & \\
\hline \multirow{4}{*}{ Forestry } & Teak & 0,35 & \multirow{4}{*}{0,81} & \multirow{4}{*}{0,58} \\
\hline & Mahogany & 0,06 & & \\
\hline & Gmelina & 0,26 & & \\
\hline & Soap & 0,14 & & \\
\hline \multirow{4}{*}{ Horticulture } & Lada & - & \multirow{4}{*}{0,89} & \multirow{4}{*}{0,63} \\
\hline & Chili & 0,60 & & \\
\hline & Rambutan & 0,11 & & \\
\hline & Durian & 0,17 & & \\
\hline Total Used & & & 72,17 & 51,37 \\
\hline Unplanted & & & 68,33 & 48,63 \\
\hline Total & & & 140,50 & 100,00 \\
\hline
\end{tabular}

Results and Discussion

\section{Types of Agroforestry in Boalemo}

Based on the results of the research, the agroforestry system applied by farmers in Boalemo Regency is a simple agroforestry system, because it combines trees with one or more types of crops a season.

Table 1. Agroforestry land use

Source: Processed primary data (2018) 
Farmers combine annual crops that have high to low economic value. Based on the time scale, the agroforestry system being cultivated is the initial agroforestry. Early agroforestry was characterized by a larger area of agricultural crops than forest crops. The results of the research in the field explain that the total land area of agroforestry farmers is 140.50 ha (Table 1).

The area of land used for agricultural crops is 71.36 ha or $50.79 \%$ of the total area of agroforestry. The land area for agricultural crops is divided into three, namely for food crops of 50.35 ha (35.84\%), plantations of 20.12 ha (14.32\%), while for horticultural crops it is 0.89 ha $(0.63 \%)$. . The land used for forestry commodities alone is only 0.81 ha or $0.58 \%$ of the total area of agroforestry farmers and $48.63 \%$ of the rest has not been planted. According to Mahendra (2009), the formation of the initial agroforestry system was triggered by the level of population pressure on the land. For farmers who have no income outside of agricultural products, this system is absolute, while farmers who have outside income have a relatively low level of dependence on land. This condition makes farmers try to use their land intensively by planting other types of both fruit-producing and wood-producing plants.

\section{Agroforestry Revenue}

Agroforestry income is the result of the accumulation of total income from food crops, plantations, forestry and horticulture. Based on the results of income calculations, the average total agroforestry income is Rp. 205,055,153/ha/year with a total income of Rp. $249,280,098 /$ ha/year and the total cost or total cost is Rp.44,224,945/ha/year (Table 2). The largest revenue contribution was obtained from horticultural crops, which amounted to Rp.92,394,958/ha/year with a total revenue of Rp.97,599,164/ha/year and a total cost of Rp.5,204,206/ha/year. The most widely cultivated horticultural crop is cayenne pepper. Suparwata \& Ulfiasih (2017), stated that chili is a horticultural plant that has high economic value. The Central Bureau of Statistics of Boalemo Regency (2017), reported that the type of vegetable plant with the highest production was cayenne pepper with 44,093 tons.

Table 2. Average total agroforestry income

\begin{tabular}{|c|c|c|c|}
\hline Commodities & $\begin{array}{c}\text { Total Cost } \\
\text { (Rp/ha/Year) }\end{array}$ & $\begin{array}{c}\text { Admission } \\
\text { (Rp/ha/Year) }\end{array}$ & $\begin{array}{c}\text { Revenue } \\
\text { (Rp/ha/Year) }\end{array}$ \\
\hline Food & 6.326 .693 & 13.080 .260 & 6.753 .567 \\
\hline Plantation & 10.144 .386 & 57.371 .394 & 47.227 .009 \\
\hline Horticulture & 5.204 .206 & 97.599 .164 & 92.394 .958 \\
\hline Forestry & 22.549 .660 & 81.229 .279 & 58.679 .619 \\
\hline TPA & 44.224 .945 & 249.280 .098 & 205.055 .153 \\
\hline
\end{tabular}

Source: Processed primary data (2018)

The agricultural pattern in Boalemo Regency includes the forestry component with a total income of Rp. $58,679,619 /$ ha/year or $28.62 \%$ of the total income of agroforestry (Figure 1 ). The agricultural component includes several commodities, including plantation crops with a total income of Rp.47,227,009/ha/year, for horticultural crops and food crops, the total income is Rp.6,753,567/ha/year.

The smallest income contribution is obtained from food crops, which is $3.29 \%$ of the total income of agroforestry. Based on the results of interviews obtained directly from farmers, the small contribution of food crop commodities is caused by several factors. These factors include: 
1) market prices are still fluctuating, 2) minimal yields due to pests and plant diseases, 3) the amount of input production costs for each growing season. At the time of the study, the average price of corn at the farmer level was Rp. 2,500.

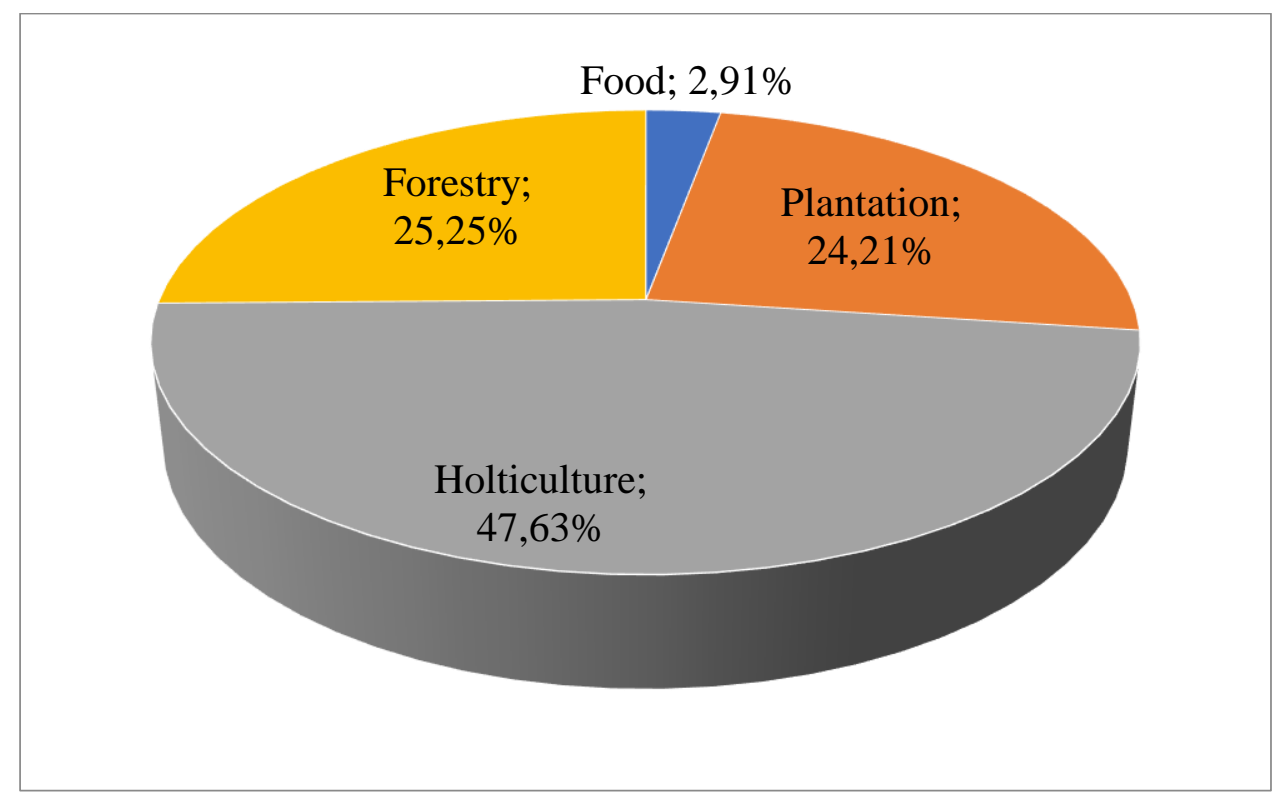

Figure 1. Percentage of agroforestry revenue

\section{Conclusion}

Based on the results of research and discussion, it can be concluded that agroforestry in Boalemo Regency is classified as simple agroforestry, while based on the time scale it is classified as early agroforestry. The total income of agroforestry (PTA) is Rp. $205,055,153 /$ ha/year, the total revenue is Rp. $249,280,098 /$ ha/year and the total cost is Rp.44,224,945/ha/year. It is hoped that the government of Boalemo district in particular and Gorontalo Province in general will encourage farmers to carry out conservation farming for the realization of sustainable agriculture.

\section{References}

Fanish, S. A., \& Priya, R. S. (2013). Review on benefits of agro forestry system. International Journal of Education and Research, 1(1), 1-12.

Khasanah, N., Biahimo, S. D. J., Dwiyanti, E., \& Sugeng, S. (2016). Menuju Kawasan Pertanian yang Produktif dan Berkelanjutan di Kecamatan Tilamuta, Kabupaten Boalemo, Gorontalo. World Agroforestry Centre (ICRAF) Southeast Asia Regional Program, Bogor, Indonesia..

Mahendra, F. (2009). Sistem agroforestri dan aplikasinya. Graha Ilmu. Yogyakarta.

Mulyana, L. (2017). Performa Pengelolaan Agroforestri Di Wilayah KPHL RAJABASA.

Silaen, S. (2013). Widiyono. Metode Penelitian Sosial untuk Penulisan Skripsi dan Tesis.

Sundari, M. T. (2011). Analisis biaya dan pendapatan usaha tani wortel Di kabupaten karanganyar. SEPA: Jurnal Sosial Ekonomi Pertanian dan Agribisnis, 7(2).

Suparwata, D.O., \& Ulfiasih. (2017). Konservasi dan Keberlanjutan Pertanian: Suatu Kajian Metode Penerapan KTA oleh Petani Pedesaan. Prosiding Seminar Nasional Pertanian. 
Wiratani dalam Agribisnis Indonesia: Fakta Harapan dan Tantangan. Universitas Muhammadiyah Makassar 